\title{
STRATEGI SISWA KELUARGA MISKIN DALAM MEMEMPERTAHANKAN PRESTASI BELAJAR DI SMA NEGERI 4 TAKALAR
}

\author{
Yuyun Nur Rezki ${ }^{1}$, Zainal Arifin ${ }^{2}$ \\ ${ }^{1,2}$ Program Studi Pendidikan Sosiologi, Fakultas Ilmu Sosial, Universitas Negeri Makassar \\ nurrezkiyuyun@gmail.com ${ }^{1}$, zainal.arifin@unm.ac.id ${ }^{2}$
}

\begin{abstract}
ABSTRAK
Penelitian ini bertujuan untuk mengetahui: 1) Starategi siswa keluarga miskin dalam mempertahankan prestasi belajar di SMA Negeri 4 Takalar. dan 2) Bentuk dukungan orangtua terhadap siswa keluarga miskin dalam mempertahankan prestasi belajar di SMA Negeri 4 Takalar. Jenis penelitian ini kualitatif deskriptif dengan penentuan informan melalui teknik purposive sampling dengan kriteria yaitu siswa kelas XII yang berprestasi dari peringkat 1-3 yang mendapatkan kartu indonesia pintar dan orangtua siswa kelas XII yang berprestasi dari peringkat 1-3 yang mendapatkan kartu indonesia pintar, dengan jumlah informan 22 orang. Teknik pengumpulan data yaitu observasi, wawancara, dan dokumentasi. Teknik analisis data kualitatif deskriptif melalui tiga tahap yaitu reduksi data, penyajian data, dan penarikan kesimpulan. Teknik pengabshan data menggunakan member check. Hasil penelitian ini menunjukkan bahwa: 1)Strategi siswa keluarga miskin dalam mempertahankan prestasi belajar di SMA Negeri 4 Takalar: (a) Strategi hubungan b) strategi kognitif dan (c) strategi komunikasi. 2) Bentuk dukungan orangtua terhadap siswa keluarga miskin dalam mempertahankan prestasi belajar di SMA Negeri 4 Takalar, yakni:(a) dukungan finansial. (b) dukungan motivasi dan (c) dukungan pola didik.
\end{abstract}

Kata kunci: Strategi, Keluarga miskin. Prestasi belajar

\section{ABSTRACT}

The study aims to find out: 1) Starategi students of poor families in maintaining learning achievement at SMA Negeri 4 Takalar. and 2) The form of parental support towards the poor family students in maintaining the achievement of study at SMA Negeri 4 Takalar. This type of research is qualitative descriptive with the determination of the informant through the technique of purposive sampling with the criteria of the grade XII students who accomplished from the rank 1-3 who received a smart Indonesia card and parents of the class XII students who Achievers from the rank 1-3 who received the card Indonesia Smart, with the number of informant 22 people. Data collection techniques are observations, interviews, and documentation. A qualitative and descriptive data analysis technique through the three stages of data reduction, data presentation, and withdrawal of conclusions. Data wiring techniques using member check. The results of this study showed that: 1) The strategy of poor family students in maintaining the achievement of learning in the state High School 4 Takalar: (a) Relationship strategy B) Cognitive strategies and (c) communication strategies. 2) The form of parental support towards poor family students in maintaining study achievement at SMA Negeri 4 Takalar, namely: (a) financial support. (b) Motivation support and (c) student support.

Keywords: Strategy, Poor family, learning achievment

\section{PENDAHULUAN}

Keluarga merupakan agen sosialisasi yang pertama membentuk kepribadian serta pola tingkah laku anak. Proses sosialisasi yang terjadi dikeluarga anak akan mengenal figur orangtua, saudara, maupun kerabaat terdekat yang memiliki tugas untuk mendidik anak memperoleh dasar-dasar pola pergaulan hidup yang baik. Keluarga merupakan salah satu unik terkecil di dalam kelompok masyarakat, dimana di dalam keluarga terdapat ayah, ibu dan anak.

Setiap anak diberikan pola pendidikan keluarga sesuai dengan fase-fase perkembangannya. Pada fase perkembangan remaja penanaman nilai kedisiplinan, 
pengetahuan, perhatian serta pemberi kebebasan dalam pengawasan orangtua untuk menunjang keberhasilan studi anak, orangtua memiliki peranan penting yaitu menumbuhkan motivasi anak, menanamkan nilai-nilai pendidikan agar anak memiliki pengetahuan, memberikan pengertian, serta memberikan tambahan pelajaran untuk anak di luar sekolah (Gunarsa, 2000).

Setiap orangtua berbeda- beda dalam menerapkan sosialisasi terhadap anak. Hal ini disebabkan oleh perbedaan pendidikan, lingkungan dan pendapatan orangtua. Tingkat pendidikan orangtua yang tinggi akan memiliki kecerdasan serta mampu menerapkan pola asuh yang sesuai kepada si anak. Lingkungan berpengaruh besar terhadap pola tingkah laku anak, ketika keluarga tinggal di lingkungan yang kurang baik sangat banyak peluang bagi si anak untuk melakukan tindakan yang kurang baik (Gunarti \& Muis, 2014). Pendapatan orangtua sangat penting karena kemampuan orangtua menjadikan kecerdasan anak didukung dengan biaya yang biasanya banyak. Hal seperti inilah yang biasa menjadi masalah bagi anak seharusnya mereka menikmati masa-masa berkembangnya dengan belajar dengan giat,mengikuti temabahan pelajaran di luar sekolah. Akibat ketidakmampuan orangtua anak sehingga mereka tidak bisa menikmati hal tersebut.

Kemiskinan adalah suatu kondisi dimana seseorang tidak mampu untuk memenuhi kebutuhan dasarnya seperti pangan, sandang, tempat tinggal, pendidikan, dan kesehatan yang layak.(Bastiana, Najamuddin, \& Rasyid, 2019) Pendapatan orangtua merupakan faktor yang sangat penting karena kemampuan orangtua menjadikan kecerdasaan anak didukung dengan biaya yang banyak. Dalam dunia pendidikan menyertakan lingkungan sekolah terdapat peserta didik yang terbagi beberapa macam keluarga dan kelas sosial yang berbeda. Perbedaan ini sangat berpengaruh terhadap sikap siswa, cara berinterkasi yang berasal dari keluarga miskin dengan keluarga yang berada. Siswa yang berasal dari keluarga yang berada biasanya sangat mudah berinteraksi dengan siswa lainnya dan memiliki fasilitas yang lengkap sebagai media untuk belajar. Sedangkan siswa yang berasal dari keluarga miskin pasti berbanding terbalik dengan siswa yang berada, mereka hanya memiliki kemampuan untuk berpikir dan memiliki peralatan sekolah dengan seadanya.

Untuk mempertahankan prestasi siswa yang berkeluarga miskin dengan cara belajar dengan giat, aktif dalam berorganisasi siswa intra sekolah. Aktif dalam pembelajaran siswa tersebut juga melakukan beberapa kegiatan untuk tetap bertahan yaitu bekerja setelah pulang sekolah dengan membantu orangtua, bekerja dengan orang lain untuk mendapatkan tambahan biaya sekolah. Strategi inilah yang digunakan siswa tersebut untuk tetap mempertahankan sekolah serta bertahan juga dalam prestasi dilakukan anak tesebut dengan sangat sulit meskipun tidak semudah yang dirasakan teman-temannya.

Fenomena ini terlihat di SMA Negeri 4 Takalar. Berdasarkan pengamatan awal penulis terlihat siswa meskipun berasal dari keluarga yang bisa dikatakan kurang mampu, tetapi siswa tersebut masih mampu meningkatkan prestasinya. Sehingga penulis tertarik untuk mengetahui strategi yang digunakannya. Terdapat beberapa siswa yang berprestasi meski berasal dari keluarga miskin yang duduk di kelas X, XI, dan XII karena prestasi mereka memperoleh bantuan berupa beasiswa dari sekolah. Beasiswa tersebut, mereka dapat memenuhi kebutuhan sekolah seperti seragam sekolah dan kartu pintar, sehingga dapat pula meringankan beban orangtua mereka yang sebagian besar bekerja sebagai, petani, nelayan dan wiraswasta.

Data administrasi SMA Negeri 4 Takalar. menunjukkan bahwa terdapat 1092 jumlah siswa untuk tahun ajaran 2018-2019. Siswa tersebut berasal dari berbagai latar 


\section{Jurnal Sosialisasi \\ Jurnal Hasil Pemikiran, Penelitian, dan Pengembangan \\ Keilmuan Sosiologi Pendidikan \\ Vol 7, Nomor 1, Maret 2020}

belakang ekonomi. Jumlah siswa kelas X tercatat sebanyak 394 orang, jumlah siswa kelas XI tercatat sebanyak 357 orang, jumlah siswa XII tercatat sebanyak 341 orang.

Meskipun ada strategi yang dilakukan bertentangan dengan keluarga dan harus meluangkan waktu yang sangat banyak untuk menyelesaikan kegiatan tersebut dengan baik. Pertentangan yang mereka alami tersebut tidak menjadi halangan siswa memiliki prestasi di sekolah. Walaupun banyak kegiatan di sekolah meski dilakukan dan di luar sekolah juga akan tetap dilakukan. Tujuan penelitian ini untuk mengetahui Strategi siswa keluarga miskin dalam mempertahankan prestasi belajar dan bentuk dukungan orangtua terhadap siswa keluarga miskin dalam mempertahankan prestasi belajar.

\section{METODE PENELITIAN}

Jenis penelitian ini adalah kualitatif dengan pendekatan deskriptif. Lokasi SMA Neheri 4 Takalar. Teknik penentuan informan adalah purposive sampling, penentuan informan melalui teknik purposive sampling dengan kriteria yaitu siswa kelas XII yang berprestasi dari peringkat 1-3 yang mendapatkan kartu indonesia pintar dan orangtua siswa kelas XII yang berprestasi dari peringkat 1-3 yang mendapatkan kartu indonesia pintar, dengan jumlah informan 22 orang. Teknik pengumpulan data yaitu observasi, wawancara, dan dokumentasi. Teknik analisis data kualitatif deskriptif melalui tiga tahap yaitu reduksi data, penyajian data, dan penarikan kesimpulan. Teknik pengabshan data menggunakan member check.

\section{HASIL PENELITIAN DAN PEMBAHASAN}

\section{Strategi Siswa Keluarga Miski Dalam Mempertahankan Prestasi Belajar}

Hasil penelitian di SMA Negeri 4 Takalar, menunjukkan bahwa ada tiga strategi yang digunakan keluarga miskin untuk mempertahankan prestasi belajarnya. Ketiga strategi itu adalah strategi hubungan keluarga, strategi kognitif, strategi komunikasi. Startegi hubungan keluarga berhasil melalui masalah dengan menciptakan struktur dan organisasi yang lebih besar dirumah dan keluarga. Strategi hubungan Keluarga adalah dengan berbagai perasaan dan pemikiran serta terlihat dalam pengalaman aktivitas keluarga kebersamaan yang lebih besar menghasilkan kohesi keluarga yang lebih tinggi, atribut keluarga yang mendapatkan perhatian yang luas sebagai atribut keluarga inti. keluarga menerapkan pengedalian yang lebih besar dan mencapai integrasi dan kohesivitas yang lebih besar.

Berdasarkan hasil penelitian bahwa, strategi hubungan keluarga adalah banyak siswa yang mendaptkan peringkat dengan berbagai cara belajar yang dia gunakan dan adapun orangtua selalu mengingatkan anaknya untuk tetap rajin belajar dan dari dukungan nasihat orangtua juga sehingga mereka bisa mempertahankan prestasi belajar. Strategi hubungan keluarga pada siswa yang berprestasi dengan yang dimiliki hubungan keluarga sangat baik dan mendorong untuk selalu giat belajar dan memiliki hubungan yang baik kepada guru dan teman.

Strategi kognitif adalah kapabilitas-kapabilitas yang secara internal terorganisasi yang memungkinkan siswa menggunakan untuk mengatur cara dia belajar, mengingat dan berpikir.(Hidayati, 2019) Berbeda dengan keterampilan intelektual yang memungkinkan siswa untuk menggunakan angka-angka, kata-kata, atau simbol-simbol berada diluar lingkungan, maka strategi kognitif memungkinkan siswa mengendalikan perilakunya sendiri dalam menghadapi lingkungannya. Siswa menggunakan strategi kognitif ketika ia mengikuti berbagai urian dari apa yang sedang dibaca atau apa yang dipelajari. Siswa 
menggunakan beberapa strategi kognitif dalam memikirkan apa yang telah ia pelajari dan dalam memecahkan masalah".

Strategi kognitif keluarga menormalkan dengan ritual dan rutinitas membantu keluarga mengatasi stress dan meningkatkan rasa keutuhan sepanjang waktu, sangat penting guna menormalisasikan situasi keluarga. Keluarga yang menggunakan strategi ini cenderung melihat aspek positif dari peristiwa hidup penuh stress menjadi tidak terlalu penting dalam hirarki nilai keluarga. Hal ini ditandai dengan anggota keluarga yeng memiliki rasa percaya dalam mengatasi keganjilan dengan mempertahankan pandangan optimistik terhadap peristiwa, terus memiliki harapan dan berfokus pada kekuatan potensi. Disini keluarga sangat lah penting dalam memberikan motivasi kepada anaknya. Adanya keluarga yang selalu memberikan motivasi, prestasi anak tidak akan perna menurun dan selalu menjadi peringkat di dalam kelas. Sedangkan menurut (Teresa \& Ormrod Mcdevitt (Jeanne Glenn et al.), 2019) menjelaskan bahwa strategi kognitif sebagai "specitic mental process that people use to acquire or manipulation information" jadi yang dimaksud strategi kognitif adalah proses mental atau kognitif tertentu yang digunakan orang untuk memperoleh atau memanipulasi informasi”.

Bentuk strategi kognitif misalnya orangtua memberikan motivasi kepada anaknya untuk tetap rajin belajar supaya bisa masuk di jenjang perguruan tinggi dan dapat mempertahankan prestasi. Sedangkan anak disini terus belajar rajin belajar sehingga bisa tetap mempertahankan prestasi belajar dan ketika prestasi mereka menurun mereka berusaha memecahkan masalah tersebut dengan melakukan berbagai cara seperti memperbanyak belajar, menjawab kuis atau pertanyaan dari guru serta mengerjakan tugas.

Strategi komunikasi adalah cara mengatur pelaksanaan operasi komunikasi agar berhasil. Strategi komunikasi pada hakikatnya adalah perencanaan (planning) dan manajemen (magement) untuk mencapai satu tujuan. Untuk mencapai tujuan tersebut, strategi ini tidak berfungsi sebagai peta jalan yang menunjukkan arah, tetapi juga harus menunjukkan taktik operasionalnya. Oleh karenanya dari paparan secara teori di atas, agar komunikator pada saat berkomunikasi harus bisa membuat strategi komunikasi terlebih dahulu agar pesan yang kita sampaikan bisa mencapai target komunikasi yang diinginkan. Komunikasi adalah proses penyampaian suatu pesan dalam bentuk simbol atau kode dari dari satu pihak kepada yang lain dengan efek untuk mengubah sikap, atau tindakan. "Effendy Uchjana menjelelaskan strategi komunikasi adalah tahapan konkret dalam rangkaian aktifitas komunikasi yang berbasis pada satuan teknik bagi pengimplemintasian tujuan komuniasi, adapun teknik adalah satu pilihan tindakan komunikasi tertentu berdasarkan strategi yang telah ditetapkan sebelumnya".

Strategi komunikasi terbuka dan jujur, anggota keluarga yang menunjukkan keterbukaan, kejujuran, pesan yang jelas dan perasaan serta afeksi yang lebih besar dibutuhkan pada masa ini. Satir mengamati bahwa komunikasi keluarga yang fungsional adalah langsung, terbuka, jujur dan jelas. Keterbukaan adalah komunitif dalam berbagai ide dan perasaan.(Farziah, 2019) Pemecahan masalah kolaboratif, yang dibahas sebagai strategi koping kognitif, juga merupakan strategi komunikasi, yang memfasilitasi koping dan adaptasi keluarga. D isini anak terbuka dan jujur kepada kelurga tentang apa yang dialami di sekolah semisal prestasi anak menurut, selalu memberi tahukan kepada orangtuanya. Orangtua langsung memberikan nasehat kepada anaknya.

Penelitian ini menggunakan "teori tindakan sosial merupakan suatu suatu tindakan individu yang memiliki arti atau makna (meaning) subjektif bagi dirinya dan diartikan dengan orang lain. Weber mengemukakan bahwa tindakan sosial tidak selalu memiliki rasional, tetapi terdapat berbagai tindakan nonrasional yang dilakukan oleh orang 
termaksud dalam tindakan orang dalam kaitannya dengan aspek pendidikan dari kehidupan. Max Weber mengemukakan empat tipe dari tindakan sosial, yaitu: Tindakan rasional instrumental (zweckrationalitat atau instrumentally rational action), yaitu suatu tindakan yang dilakukan berdasarkan pertimbangan dan pilihan yang dasar dalam kaitannya dengan tujuan suatu tindakan dan alat yang dipakai untuk meraih tujuan yang ada. Tindakan rasional nilai (vaalue rational action), yaitu tindakan dimana tujuan telah ada di dalam hubungan nilai absolut dan nilai akhir bagi individu, yang dipertimbangkan secara sadar adalah alat mencapai tujuan. Tindakan afektif (affectual action), yaitu tindakan yang didominasi perasaan atau emosi tanpa reflektif intelektual atau perencanaan yang sadar. Tindakan tradisional (tarditional action), yaitu tindakan karena kebiasaan atau tradisi. Tindakan ini dilakukan tanpa refleksi yang sadar perencanaan." "Max weber mengatakan tindakan sosial dimulai dari tindakan individu atau perilaku individu dengan prilaku orang lain, yang orentasikan pada hasil tindakan tersebut sehingga dapat dipahami secara subjektif, maksudnya setiap tindakan sosial yang dilakukan seseorang akan memiliki maksud atau makna tertentu, (Sugiantoro, 2012)

Jika dikaitkan dengan penelitian ini menggunakan tindakan rasional karena tindakan rasional nilai (vaalue rational action), yaitu tindakan dimana tujuan telah ada di dalam hubungan nilai absolut dan nilai akhir bagi individu, yang dipertimbangkan secara sadar adalah alat mencapaai tujuan. Karena penelitian ini menggunakan strategi siswa keluarga miskin dalam mempertahankan prestasi belajar dalam pelaksanaan strategi sudah ada tujuan-tujuan yang telah direncanakan secara sadar seperti strategi hubungan keluarga pada siswa yang berperstasi dengan yang dimiliki hubungan keluarga sangat baik dan mendorong untuk selalu giat belajar, strategi kognitif adanya keluarga yang selalu memberikan motivasi, prestasi anak selalu menjadi peringkat di dalam kelas sedangkan strategi komunikasi merupakan anak terbuka dan jujur kepada kelurga tentang apa yang dialami di sekolah semisal prestasi anak menurun, selalu memberi tahukan kepada orangtuanya dan orangtuanya langsung memberikan nasehat kepada anaknya. Tentu dalam proses tersebut keluarga sebelumnya telah mempertimbangkan segala dampaknya terutama dalam mempertahankan prestasi belajar.

\section{Bentuk Dukungan Orangtua Siswa Keluarga Miskin Dalam Mempertahankan} Prestasi Belajar

Bentuk dukungan orangtua terhadap prestasi siswa keluarga miskin dalam mempertahankan prestasi belajar di SMA Negeri 4 Takalar yaitu: dukungan finansial, dukungan motivasi dan dukungan pola didikan. Adanya bantuan Kartu Indonesia Pintar sangat besar pengaruhnya terhadap kelangsungan kehidupan keluarga. Dukungan finansial ini melibatkan bantuan langsung sesuai dengan kebutuhan individu misalnya berupa bantuan materi atau bantuan mengerjakan tugas-tugas tertentu. Di sini orangtua siswa sangat terbantu dengan adanya kartu Indonesia pintar, anak yang mendapatkan kartu Indonesia pintar dapat meringkan orantua untuk masalah biaya-biaya kebutuhan di sekolah. Keluarga yang kurang mampu mendapatkan Kartu Indonesia Pintar dengan yang berprestasi di sekolah.

Dukungan finansial yang rangtua siswa yang keluarga miskin merasa dibantu dengan adanya kartu Indonesia pintar ini dan anak yang mendapatkan kartu Indonesia pintar ini mampu meringankan beban orangtua untuk masalah pengeluaran di sekolah dan keluarga yang kurang mampu dapat meendapatkan Kartu Indonesia Pintar dengan anaknya yang berprestasi di sekolah. Kebanyakan juga ibu dari orangtua siswa yang hanya ibu rumah tangga. 
Kartu Indonesia Pintar adalah sebuah kartu yang mana diberikan kepada keluarga miskin dan rentan miskin (tidak mampu) yang mana mereka berkeinginan untuk dapat menyekolahkan anaknya yang mana anak tersebut berusia 7-18 tahun secara gratis. Mereka yang memperoleh Kartu Indonesia Pintar ini akan diberikan dana tunai dari pemerintah secara teratur yang mana dana tersebut tersimpan dalam fungsi Kartu Indonesia Pintar untuk menyekolahkan anaknya tanpa biaya alias gratis. Program Kartu Indonesia Pintar ini akan diberikan kepada 15,5 juta keluarga yang kurang mampu di seluruh Indonesia untuk setiap orang tua yang mempunyai anak usia sekolah 7 sampai dengan 18 tahun entah itu yang sudah terdaftar ataupun yang belum terdaftar kedalam sekolah ataupun madrasah. Program Kartu Indonesia Pintar ini pemerintah mengharapkan angka putus sekolah akan menurun.

Peluncuran program Kartu Indonesia Pintar ini oleh pemerintah ini ditujukan agar dapat menghilangkan kesenjangan atau hambatan ekonomi bagi siswa yang berkeinginan untuk sekolah. Diharapkan natinya akan membuat anak-anak di Indonesia tak lagi berpikiran untuk berhenti bersekolah. Selain untuk menghindari anak putus sekolah di Indonesia, Kartu Indonesia Pintar ini juga agar dapat menarik minat anak yang telah putus sekolah utnuk kembali bersekolah. Kartu Indonesia Pintar ini bukan hanya membantu para siswa dalam pembiayaan administrasi sekolah, tapi juga bertujuan untuk dapay memenuhi segala kebutuhan dalam kegiatan pembelajaran di sekolah. Tujuan yang luas lagi, Kartu Indonesia Pintar ini juga untuk mewujudkan program wajib belajar pendidikan dasar 9 tahun dan juga pendidikan menengah universal atau wajib belajar 12 tahun.

Sebagai makhluk Tuhan Yang Maha Esa, manusia dilahirkan memiliki posisi dan kedudukan yang sama dimata-Nya. Namun kenyataan yang ada di dalam masyarakat tidaklah demikian. Kondisi sosial ekonomi seseorang di masyarakat berbeda sesuai status dan perannya. Tingkat status sosial ekonomi dilihat atau diukur dari pekerjaan orangtua, penghasilan dan kekayaan, tingkat pendidikan orangtua, keadaan rumah dan lokasi, pergaulan dan aktivitas sosial (Setianingsih, 2018).

Dukungan finansial yang dihadapi orangtua siswa yang berasal dari keluarga miskin yaitu merasa dibantu dengan adanya Kartu Indonesia Pintar ini dan anak yang mendapatkan Kartu Indonesia Pintar ini dapat meringkan beban orangtua untuk masalah pengeluaran disekolah dan keluarga yang kurang mampu dapat mendapatkan Kartu Indonesia Pintar dengan anaknya yang berprestasi di sekolah. Kebanyakan juga ibu dari orangtua siswa yang hanya ibu rumah tangga.

Dukungan motivasi. sebenarnya bisa memberikan motivasi kepada anaknya dengan memberikan dorongan kepada anak untuk berusaha untuk pada tugas-tugas yang sulit, memberikan pujian dan hadiah ketika anak dapat menyelesaikan tugasnya dengan baik dan selalu memberikan saran ketika anak membutuhkan atau sedang menghadapi masalah dalm belajarnya. Di sini juga orangtua sebagai pendorong motivasi dalam prestasi belajar anak di sekolah dan orangtua juga memberikan dukungan sepeawarinuhnya terhadap anak dalam memcapai keberhasilan tersebut.

Dukungan motivasi yaitu banyak orangtua yang memberikan perhatian kepada anaknya disaat mereka malas belajar dan ada juga sebgaian orangtua yang mendorong anaknya unntuk mengapai cita-citanya serta memberikan nasehat supaya bisa masuk dijenjang bangku perkuliahan. Ada juga orangtua yang sikapnya kepada anaknya terbuka tentang masalah pelajaran atau prestasinya di sekolahnya. Mulyasa menyatakan motivasi adalah tenaga pendorong atau penarik yang menyebabkan adanya tingkah laku ke arah suatu tujuan tertentu. Peserta didik akan bersungguh-sungguh karena memiliki motivasi 
yang tinggi. Seorang siswa akan belajar bila ada faktor pendorongnya yang disebut motivasi".

Hasil penelitian menunjukkan dukungan motivasi yaitu banyak orangtua yang memberikan perhatian kepada anaknya disaat mereka malas belajar dan ada juga sebagian orangtua yang mendorong anaknya unntuk mengapai cita-citanya serta memberikan nasehat atau motivasi supaya bisa masuk dijenjang perkuliahan. Ada juga orangtua yang sikapnya kepada anaknya terbuka tentang masalah pelajaran atau prestasinya di sekolahnya.

Pola didik adalah cara yang digunakan orangtua dalam mencoba berbagai strategi untuk mendorong anak mencapai tujuan yang di inginkan. (Meisarah, 2019)Tujuan tersebut antara lain pengetahuan, nilai moral, dan standar perilaku yang harus di miliki anak bila dewasa nanti. Orangtua selalu mengarahkan anaknya untuk selalu giat belajar dan meningkatkan prestasinya di sekolah dan bisa masuk kuliah sampai bisa meraih citacitanya.

Dukungan pola didik tentang prestasi belajarnya di sekolah yaitu orangtua mengingatkan anaknya untuk rajin belajar atau mengerjakan tugas sekolah supaya prestasinya anaknya meningkat atau tidak menurun maka dari itu orangtua siswa tersebut memberikan dorongan atau motivasi kepada anaknya supaya mereka lebih giat untuk belajar dan dapat meraih cita-citanya. Anak merupakan tanaman kehidupan, buah cita-cita, penyejuk hati manusia, bunga bangsa yang sedang mekar berkembang dan putik kemanusian yang merupakan dasar terbitnya pagi yang cerah, hari esok yang gemilang guna merebut masa depan yang cemerlan, memilahara kedudukan umat serta dipundaknyalah masa depan bangsa" (Meisarah, 2019). Pendapat di atas dengan jelas menyatakan bahwa mempersiapkan dan mendidik anak sebagai elemen yang membentuk keluarga masyarakat dan bangsa. Anak merupakan unit inti yang akan membentuk unsur pertama bagi kerangka umum pembangunan bangsa yang berkembang dan penuh toleransi.

Bentuk dukungan pola didik orangtua terhadap prestasi belajarnya di sekolah yaitu orangtua mengingatkan anaknya untuk rajin belajar atau mengerjakan tugas sekolah supaya prestasi anaknya meningkat atau tidak menurun maka dari itu orangtua siswa tersebut memberikan dorongan kepada anaknya supaya mereka lebih giat untuk belajar dan dapat meraih cita-citanya.

Kemudian terkait dengan teori tindakan sosial yang digunakan dalam hal ini tindakan rasional nilai (value rational action), yaitu tindakan dimana tujuan telah ada di dalam hubungan nilai absolut dan nilai akhir bagi individu, yang dipertimbangkan secara sadar adalah alat mencapaai tujuan. Karena dalam penelitian ini mengenai strategi siswa keluarga miskin dalam mempertahankan prestasi belajar, dalam pelaksanaan tersebut tentu sudah ada tujuan-tujuan yang telah direncanakan secara sadar seperti yang dilakukan orangtua yaitu merasa dibantu dengan adanya kartu Indonesia pintar ini dan anak yang mendapatkan kartu Indonesia pintar ini dapat meringkan beban orangtua, hubungan emosional antara orangtua dan anak yaitu banyak orangtua yang memberikan perhatian kepada anaknya disaat mereka malas belajar dan cara mendidik orangtua tentang prestasi belajarnya di sekolah yaitu orangtua mengingatkan anaknya untuk rajin belajar atau mengerjakan tugas sekolah supaya prestasinya anaknya meningkat atau tidak menurun maka. Tentu dalam proses tersebut orangtua sebelum telah mempertimbangkan segala dampaknya terutama dalam mempertahankan prestasi. 


\section{PENUTUP}

Berdasarkan rumusan masalah yang diangkat dalam penelitian ini. Kesimpulannya adalah Strategi siwa keluarga miskin dalam mempertahankan prestasi belajar di SMA Negeri 4 Takalar yaitu strategi siswa keluarga miskin hubungan keluarganya sangat baik dimana siswa ini memiliki yang prestasi yang membanggakan dalam keluarganya. Disini juga kita lihat orangtuanya yang kurang mampu dengan adanya Kartu Indonesia Pintar (KIP) sangat membantu dalam memenuhi kebutuhan sekolah seperti pakaian seragam sekolah,alat tulis dan sebagainya dan siswa belajar yang lebih giat dalam mempertahankan prestasi belajar. Tidak hanya itu dengan hanya Kartu Indonesia Pintar (KIP) dapat membantu perekonomian keluarga. Bentuk dukungan orangtua yang diberikan kepada anaknya sangatlah membantu dalam memotivasi anaknya dalam belajar guna untuk mendapatkan perestasi di sekolah dan meraih cita-citanya. Bentuk dukungan orangtua dari siswa keluarga miskin dalam mempertahankan prestasi belajar di SMA Negeri 4 Takalar yaitu menunjukkan bahwa adanya strategi siswa keluarga miskin hubungan keluarganya sangat baik dimana siswa ini memiliki yang prestasi yang membanggakan dalam keluarganya. Disini juga kita lihat orangtuanya yang kurang mampu dengan adanya Kartu Indonesia Pintar (KIP) sangat membantu dalam memenuhi kebutuhan sekolah seperti pakaian seragam sekolah,alat tulis dan sebagainya. Tidak hanya itu dengan hanya Kartu Indonesia Pintar (KIP) dapat membantu perekonomian keluarga. Bentuk dukungan orangtua yang diberikan kepada anaknya sangatlah membantu dalam memotivasi anaknya dalam belajar guna untuk mendapatkan perestasi di sekolah dan meraih cita-citanya.

\section{DAFTAR PUSTAKA}

Bastiana, B., Najamuddin, N., \& Rasyid, R. (2019). Analisis karakteristik rumah tangga miskin di wilayah pusat Kota Makassar Provinsi Sulawesi Selatan. Seminar Nasional LP2M UNM, 1(1).

Farziah, W. I. (2019). Kepribadian Konselor Menurut Perspektif Organisasi Profesi (Kajian Konten Analisis Terhadap Karakteristik Kepribadian Konselor Konvensional). UIN Ar-Raniry Banda Aceh.

Gunarsa, Y. S. D. (2000). Asas-asas Paikologi Keluarga Idaman. BPK Gunung Mulia.

Gunarti, W., \& Muis, A. (2014). Metode Pengembangan Perilaku dan Kemampuan Dasar AUD.

Hidayati, H. (2019). Meningkatkan Hasil Belajar Melaui Metode Quantum Learning Dengan Konsep Mind Mapping Pada Mata Pelajaran Ski Siswa Mts Negeri DaluDalu Kabupaten Rokan Hulu.

Meisarah, T. (2019). Hubungan Pola Asuh Orang Tua Dengan Kemampuan Interaksi Sosial Remaja Di Kelurahan Labuh Baru Barat Kecamatan Payung Sekaki Pekanbaru. Universitas Islam Negeri Sultan Syarif Kasim Riau.

Setianingsih, S. A. (2018). Pengaruh Status Sosial Ekonomi Orang Tua Dan Gaya Hidup Terhadap Perilaku Konsumtif Mahasiswa (Studi Kasus Mahasiswa Fakultas Ekonomi dan Bisnis Islam IAIN Purwokerto). IAIN Purwokerto.

Sugiantoro, S. (2012). Pengaruh faktor-faktor interaksi edukatif terhadap perilaku sosial siswa kelas xi jurusan ilmu sosial di SMA Negeri 1 Porong: tinjauan teori tindakan sosial Max Weber. UIN Sunan Ampel Surabaya.

Teresa \& Ormrod Mcdevitt (Jeanne Glenn et al.), E. \& C. (2019). Child Development And Education. Pearson Education Australia. 
Jumal Sosialisasi

Jurnal Hasil Pemikiran, Penelitian, dan Pengembangan Keilmuan Sosiologi Pendidikan Vol 7, Nomor 1, Maret 2020 